\title{
砕石路を走行する建設運搬車両用大型 タイヤの効果的稼働管理
}

\author{
江口忠臣 ${ }^{1} \cdot$ 室達朗 ${ }^{2}$ \\ '正会員 明石工業高等専門学校講師 都市システム工学科（テ674-8501 兵庫県明石市魚住町西岡 679-3） \\ $2 フ ェ ロ$ 会員 工博 愛媛大学教授 工学部環境建設工学科（テ790-8577 愛媛県松山市文京町3）
}

\begin{abstract}
本研究は建設車両用大型タイヤの稼働中における詳細な空気圧変動を把握し，実際の稼働管理に供する手法の検討を行 うものである. 従来, タイヤ空気圧については稼㗢中において一定であると見なされてきた. タイヤ空気圧の適正管理の 考え方は現場における稼働管理の基本を成すものである. 砕石路を走行する建設運般車両用大型タイヤについて, 空気圧 の詳細を長期にわたり調查した結果，考慮すべき変動を有することが判明した．空気圧の変動はタイヤ内部の発熱に起因 していることが明らかになった. また空気圧変動が種々のタイヤ性能に影響を及ぼすことを検証し，特に施工管理学上重 要な而摩耗性向上に奇与する稼働管理について述べた。本結果は建設車両用大型タイヤ性能維持に関して, 従来の管理手 法以外にも多様な側面を含んでいることを示している.
\end{abstract}

Key Words : OR tire, inflation pressure, wear

\section{1. 緒言}

建設車両用タイヤは，OR タイヤ (Off - the - Road Tire）と呼ばれ，一般道路以外の不整地を走行するダン プトラック, スクレーパ, ショベルローダ, グレーダ, タイヤローラ, ホイールクレーンなどの建設機械に装着 される. OR タイヤは, 建設車両の発展と共に成長して きたが，この歴史は比較的浅い. 建設車両自体 1900 年 代になって履帯式のものが使われ始め, タイヤ式はその 優れた機動性と乗り心地の良さにより 1940 年頃より取 り入れられ始めた. 建設車両は当初アメリカで発展し， 日本では戦後普及し, 戦後のダム建設, 住宅造成, 道路, 港湾建設, 採石場, 鉱山採掘などと共に大きく発展を遂 げてきたが，この中で OR タイヤも広範囲に使われる ようになった。

近年，建設運搬車両である重ダンプトラックは大型 化され，国内においても積載量 $180 \mathrm{tf}$ クラスのものも 稼働している. それに伴い，重ダンプトラックに装着さ れている大型タイヤについても大型化が進んでいる.

OR タイヤは建設車両の性能を左右する重要なものであ るが，タイヤと接触路艋の相互作用の観点から力学的現 象が複雑であり未解明な部分が多く，従来からの経験的
な範冊でその現象を捉えることを常としてきた ${ }^{1)}$.

OR タイヤは接触する相手からの反力を得て初めて性 能を発揮することができる. タイヤが地表面から得る反 力は主として接触面の摩擦力に依存することになる.

ニューマチックタイヤの特長はタイヤ内に空気圧を 保持することにより荷重支持機能を発揮するということ であり，ユーザー側においてもごく自然に受けとられて いる. したがってタイヤ性能維持のためにも空気圧の管 理については注意が払われている. 建設車両における夕 イヤ空気圧は大気圧に比べて非常に高いため, 空気圧管 理についてはもっぱら空気洩れの補充である.

大型 OR タイヤについて, 空気圧はタイヤの性能に大 きな影響を与えるため, その管理は従前から重要視され てきた. しかしながら，各現場における空気圧の適正值 は，タイヤ製造元から各タイヤに対する推奨值が示され ているものの, 現場状況に応じて管理が行われている. これまで，現場における建設機械の耐用問題として OR タイヤ空気圧に対する施工管理学的アプローチは数少な い. 建設車両の大型化が進む中, 稼働中の重ダンプトラ ックの操作性について現場オペレータがその変化を感得 するという問題が生じている. このことは, 従来のOR タイヤの取扱いが稼働中の空気圧を一定と見なしてきた 
ことに詨して，実際には空気圧変動を生じている可能性 を示している. タイヤは車両中においてばね系の役割を 果たしており，コーナリング特性，振動特性に大きな影 響を与える. また, タイヤの負荷能力はタイヤボリュー ムが一定であれば，空気圧によって決まる. これら走行 特性はタイヤ空気圧が一定であれば稼㗢中変化しないと いえる.オペレータの作業環境安定化および連続稼働に おけるタイヤ空気圧の常時管理を実現するためには, 現 場におけるタイヤユーザとして, 空気圧の変動実態を十 分に認知しておくことは不可欠である. 本研究の目的は 近年大型化する建設車両用大型 OR タイヤについて空 気圧変動の害態把握を行い, その原因と管理手法を考察 することである. OR タイヤについて空気圧変動の実 態把握を行うために, 石灰岩採石現場で実際に稼働して いる重ダンプトラックの OR タイヤについて空気圧を 測定し, 空気圧に影響を及ぼす要因について調査する. また, 空気圧と摩耗との関係を現地実験により明らかに し, 摩耗を抑えることによりタイヤ寿命を向上させるこ とを検討し, 現場における最適な OR タイヤの管理手 法を考察する.

\section{2. タイヤの特性}

\section{（1）タイヤの機能}

OR タイヤは，一般道路以外の不整地を走行する建設 機械に装着される. これらの車両の使用領域は, 砕石地, 岩盤, 軟弱地, 泥ねい地, 森林内などと極めて多岐にわ たる. 大規模土工，鉱山，等の土砂，砂利，鉱石の運搬 作業にダンプトラックを使用する場合がきわめて多い. ダム工事では山地の急坂道を長時間連続して走行すると か, 岩石の塊やずりなどを運搬するような作業に普通ダ ンプトラックを使うと車体に無理がかかり, 破損するこ とがある. これらの特殊な作業条件のもとでも耐久性を 発揮し，十分使用に耐えるように設計されたダンプトラ ックを重ダンプトラックと呼ぶ.

タイヤの基本機能は, 一般的に, 次に挙げるもので ある2).

(1)荷重を支持する

(2)路面の凹凸による衝撃を緩和する

(3)駆動力・制動力を走行路面に伝達する

(4)コーナリングフォースを発生し路面に伝える

これらの基本機能に加えて OR タイヤには性能発揮 のため次のことが要求される.

(1)荷重支持圧力容器としての耐久性

(2)耐カット性

(3)而爇性

(4)而擵耗性

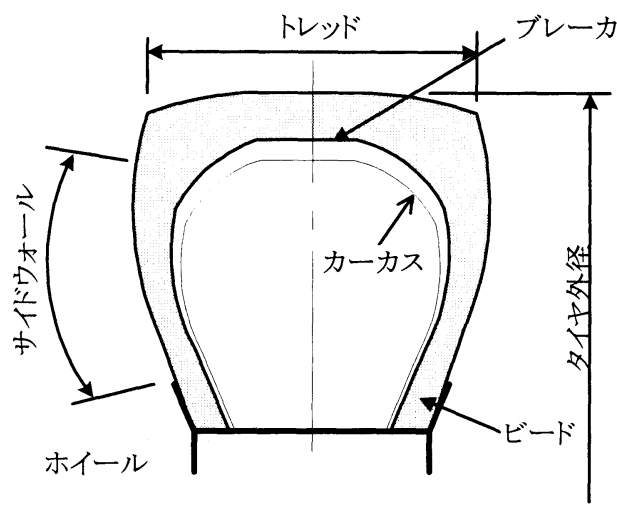

図一1 タイヤの構造

(5)軟弱地盘におけるトラクション性

基本構造としては図-1 に示寸ように，トレッド，カ 一カス, ブレーカ, ビードから構成され，各部の役割は 以下の通りである.

トレッド : タイヤが路面と接するゴム層の部分であ り，カット外傷からのカーカスを保護寸 る役割と, トレッドパターンにより作業 におけるけん引力，而擵耗等の性能を発 揮する.

カーカス : タイヤの骨格と空気圧を支持し, 荷重を 支え，路面からのショックを吸収する.

ブレーカ : カーカスの衝撃緩和とトレッドに生じた 外傷が直接カーカスに達するのを防ぐ役 割を持つ。

ビード : リムと接している部分. カーカスコードの 両端を支持し，タイヤをリムに固定する役 割で, ピアノ線で束ねている.

タイヤのトレッドパターンは，タイヤ表面に刻まれ た模様のことでタイヤの性能発揮のため用途に合わせて 選択される. パターンと特長を以下に示す.

リブ型 : タイヤの回転方向にトレッド溝が切られてお り，横方向スリップによく抵抗するため 操緥安定性がよい.

トラクション型 : 有効けん引力を路盤へ十分に伝達す るために設計されており, トレッド溝の 方向がタイヤ回転方向に対して傾斜して いる.

ロック型 : 特に岩石採石場においてアースムーバサー ビス，グレーダサービス，ローダ\&ドー ザサービスまであらゆる用途に対応する. 耐カット性, 耐摩耗性に優れていること 
も特徴である.

ブロック型: ボタンの密集したトレッドを有し，フロ ーテーションを重視した構造である. 軸 荷重の増加によって接地面積が増加する ので, 軟弱地盤での支持力を確保するこ とができる.

スムース型：トレッド溝が存在しないものであり転圧 用タイヤやローラに装着されている.

\section{(2) ORタイヤの摩耗}

大規模土工で用いられる重ダンプトラックの OR タ イヤは，過酷な使用条件により著しい摩耗を生じること が多く, タイヤ交換の費用とそのための稼働率低下は, 重ダンプトラック使用上の大きな問題とされている. 摩 耗を低減させる方法を以下に示す ${ }^{3)}$ ，4).

(1)タイヤのゴム材質の耐摩耗性, 耐カット性およひ耐 熱性の向上

(2)サイドカットに対する安定性を増大させるための夕 イヤ構造の改善

(3)タイヤ空気圧の適正な管理

(4)走路勾配の緩和や急カーブ数の減少

(5)急速な加速・減速の回避

タイヤの空気圧の大小は，タイヤのほとんど総ての 特性に大きな影響を与える重要な要因である. 適正空気 圧は車両の種類, 荷重, 速度等の条件で決定し規格化さ れており，タイヤの接地形状，タイヤのたわみ等が適正 に保たれ，タイヤの性能が十分発揮できるようになって いる. これらの条件が維持されないと, タイヤは様々な 故障を誘発すると共に, 而擵耗性も低下する。 一般に, 空気圧過多は中央摩耗，空気圧過小は両肩落ち摩耗とな り，局部摩耗を促進する.

\section{3. 調查方法}

\section{（1) 調查現場の特性}

調査現場は石灰岩露天掘り鉱山であり, 平均標高 1,200 mであった. ベンチカット（高さ $15 \mathrm{~m}$ ）工法により石 灰岩を採掘し，重ダンプトラックにより積み込み運搬を 行っている. 年間雨量は $3,000 \sim 5,000 \mathrm{~mm}$ を記録し，濃 霧の発生は年間 130〜150 日に及んでいる. 気温は最高 $28^{\circ} \mathrm{C}$ ，最低 $-10^{\circ} \mathrm{C}$ である. 路盤は石灰岩盤上に破砕し た石灭岩を敷き均し，グレーダーによって平滑に整備さ れている. 石灰岩の力学的定数は，一軸土縮強度 $42.4 \pm$ 13.1 $\mathrm{MPa}$, 引張強度 $3.8 \pm 1.0 \mathrm{MPa}$, みかけ比重 2.68 , シ ヨア硬さ $35.1 \pm 2.4$ ，超音波伝播速度 $2988 \pm 441 \mathrm{~m} / \mathrm{s}$ およ びロサンゼルスすりへり減量 $34.0 \%$ である．また，対象 岩盤は亀裂の少ないものであった。調查の対象車両は

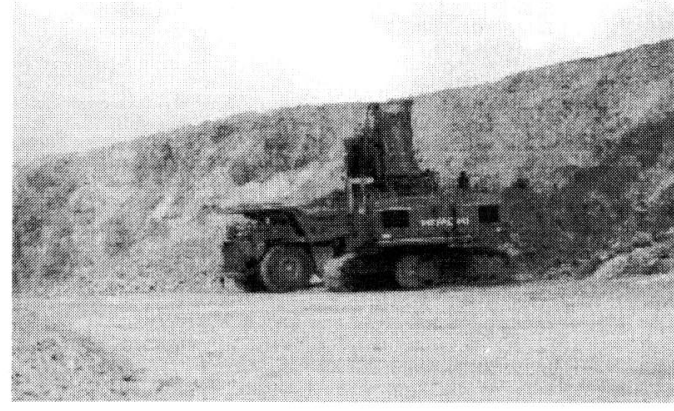

図ー2 ずりの積込作業

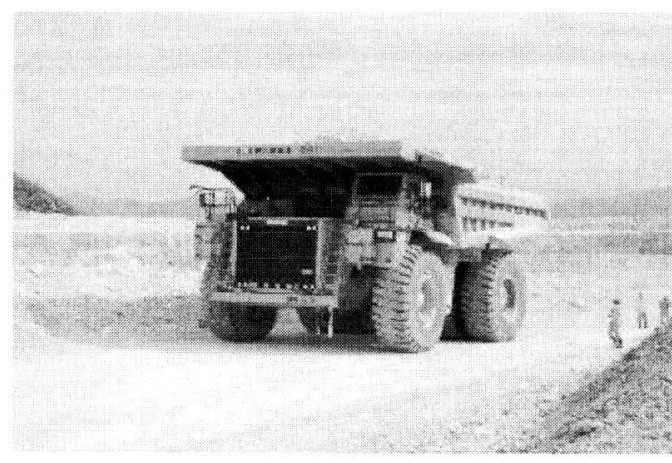

図ー3 ずり積載時の $180 \mathrm{t} \mathrm{f}$ 積み重ダンプトラック

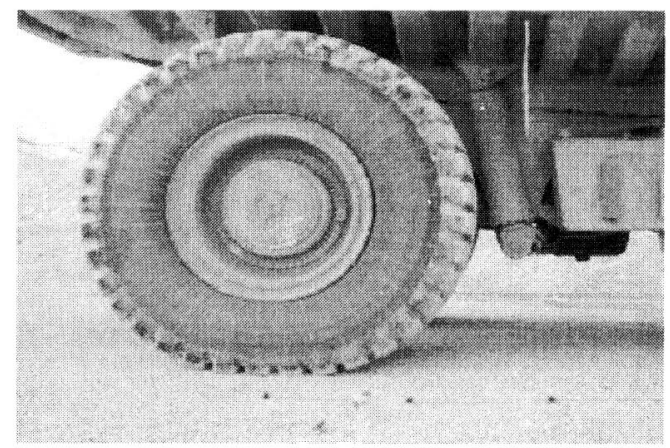

図-4 タイヤの外観

稼働中の $180 \mathrm{tf}$ 積み重ダンプトラック及びアーティキ ュレート型 $30 \mathrm{tf}$ 積み重ダンプトラックである. ベンチ カットサイトからずり投入立坑までの平均運搬距離は, 1,500mである. 図一2 はベンチカットサイトでのずり積 込作業の様子である.

\section{(2) 調査対象車両とORタイヤ a) 180tf 積み重ダンプトラック}

表一1に調查対象とした $180 \mathrm{tf}$ 積み重ダンプトラック と ORタイヤの諸元を示寸。

また図ー3にずり積載時の状況を示寸，積載時平均 
表一1 $180 \mathrm{tf}$ 積み重ダンプトラックおよび $\mathrm{OR}$ タイヤ諸元

\begin{tabular}{|c|c|c|c|}
\hline \multicolumn{2}{|c|}{ 重ダンプトラック } & \multicolumn{2}{c|}{ OR タイヤ } \\
\hline 積載重量 $(\mathrm{kN})$ & 1735 & 呼び & $3300-R 51$ \\
\hline 軸距 $(\mathrm{mm})$ & 5500 & 規格内圧 $(\mathrm{kPa})$ & 300 \\
\hline 前軸車輪間距離 $(\mathrm{mm})$ & 5200 & 外径 $(\mathrm{mm})$ & 1505 \\
\hline 後軸車輪間距離 $(\mathrm{mm})$ & 4150 & 有効駆動半径 $(\mathrm{mm})$ & 932 \\
\hline 最小回転半径 $(\mathrm{m})$ & 13.8 & タイヤ幅 $(\mathrm{mm})$ & 898 \\
\hline 前軸荷重 $(\mathrm{kN})$ & $398.3 \pm 3.8$ & トレッド幅 $(\mathrm{mm})$ & 78.5 \\
\hline 後軸荷重 $(\mathrm{kN})$ & $797.6 \pm 6.5$ & 初期溝深さ $(\mathrm{mm})$ & \\
\hline
\end{tabular}

（注）前軸荷重及び後軸荷重は空車時においての值

表-2 30tf 積み重ダンプトラックのおよび $\mathrm{OR}$ タイヤ諸元

\begin{tabular}{|c|c|c|c|}
\hline \multicolumn{2}{|c|}{ 重ダンプトラック } & \multicolumn{2}{c|}{ OR タイヤ } \\
\hline 積載重量 $(\mathrm{kN})$ & 267 & 呼び & $23.5-\mathrm{R} 25$ \\
\hline 空車重量 $(\mathrm{kN})$ & 217 & 規格内圧 $(\mathrm{kPa})$ & 525 \\
\hline 総重量 $(\mathrm{kN})$ & 484 & 外径 $(\mathrm{mm})$ & 7000 \\
\hline ホイールベース $(\mathrm{mm})$ & 4655 & 有効駆動半径 $(\mathrm{mm})$ & 612 \\
\hline 最小回転半径 $(\mathrm{m})$ & 7.6 & タイヤ幅 $(\mathrm{mm})$ & 35.8 \\
\hline 全長 $(\mathrm{mm})$ & 9940 & 初期溝深さ $(\mathrm{mm})$ & \\
\hline
\end{tabular}

速度は $12 \mathrm{~km} / \mathrm{h}$ であった. このクラスの $\mathrm{OR}$ タイヤの形 状は一般公道を走行するダンプトラックに装着されて いるタイヤとほぼ相似形をしており，10.00-20R タイ ヤをサイズアップした外観を有している. 図ー4にタイ ヤの外観を示す．トレッドパターンはロック型である.

\section{b) 30tf 積み重ダンプトラック}

調査を行った 30tf 積み重ダンプトラックは車体を屈 折して操舵するアーティキュレートダンプトラックで あり, 従来の重ダンプトラックと比べて操作性や運転 環境を大きく進化させた 3 軸 6 輪駆動車である. 表-2 に諸元を示す. 特徴は積載時の走行安定性に優れ, 最 高速度 $49.3 \mathrm{~km} / \mathrm{h}$ の走行性能と小さな旋回半径でサイク ルタイムを大幅に短縮することである.

\section{(3) 調查方法}

大型 OR タイヤの空気圧変動実態を把握するために 以下に示す調査および実験を行った.

(1)平坦路を走行する $180 \mathrm{t} \mathrm{f}$ 積重ダンプトラックの空 気圧変動調查

（a）平坦路を主として走行する $180 \mathrm{tf}$ 積み重ダンプ トラックについて初期設定を規格内圧 $700 \mathrm{kPa}$ にした場合の稼働日内空気圧変動調查を行う (8 時間).

(b) 同じく初期設定を $700 \mathrm{kPa}$ にした場合の稼㗢 日内タイヤカーカス近傍温度の変動調査を行 う (8 時間). (c) 本現場でタイヤ形状維持のために設定されて いる初期空気圧 $850 \mathrm{kPa}$ 及び $950 \mathrm{kPa}$ におけ る空気圧調查を始業時および 8 時間後に行う.

(2)坂路を主として走行する $30 \mathrm{tf}$ 積み重ダンプトラッ クについて稼働日内空気圧変動調査を行う（4 時 間).

(3)180tf 積み重ダンプトラックについて初期空気圧を 規格内圧と高内圧に調整し, タイヤの摩耗量を測 定する。

調査に先立ち、リム組作業においては細心の注意が 払われる.これは空気圧測定時にエアーバルブに直接 空気圧計を接続するため, エアー洩れを最小限にする 必要があるためである. 従って長期にわたり今回のよ うな調査を行うことは，どの現場でもすぐに行えると いうことではない.

\section{4. 結果と考察}

\section{（1）平坦路を走行する重ダンプトラックの空気圧変動}

\section{a) 規格内圧における稼働日内空気圧変動}

$180 t f$ 積重ダンプトラックに装着されている OR タイ ヤの空気圧の実態を把握するために，奨励される規格 内圧 $700 \mathrm{kPa}$ に初期設定した場合の一稼働日内の空気 圧を調查した. 調査現場の通常稼働時の内圧はタイヤ の形状維持のために経験的に高めに設定しているが， 


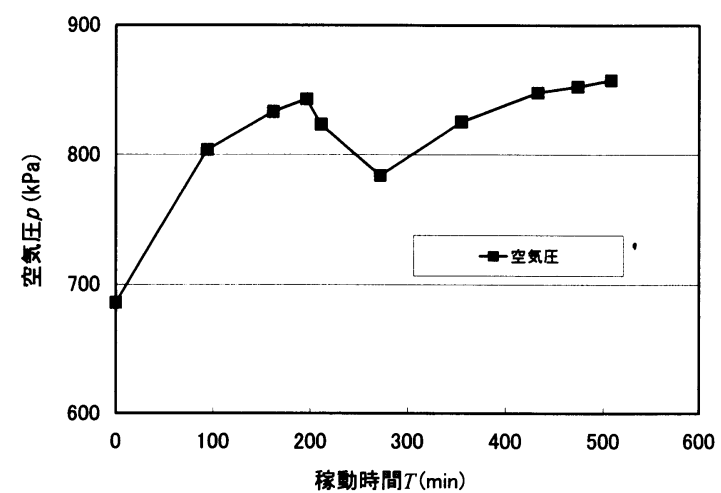

図-5 $180 \mathrm{t} \mathrm{f}$ 積重ダンプトラックの規格内圧時の空気圧変動

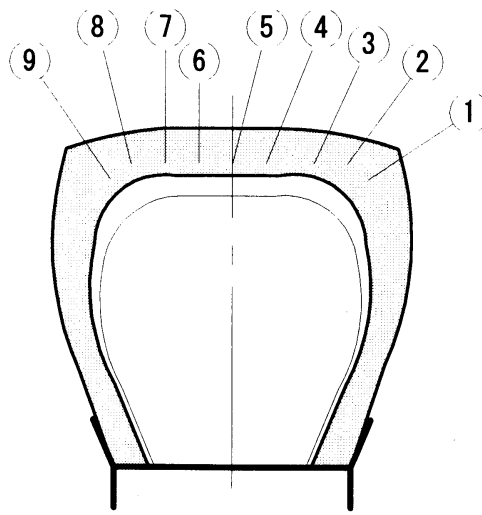

図一7 カーカス近傍温度測定箇所

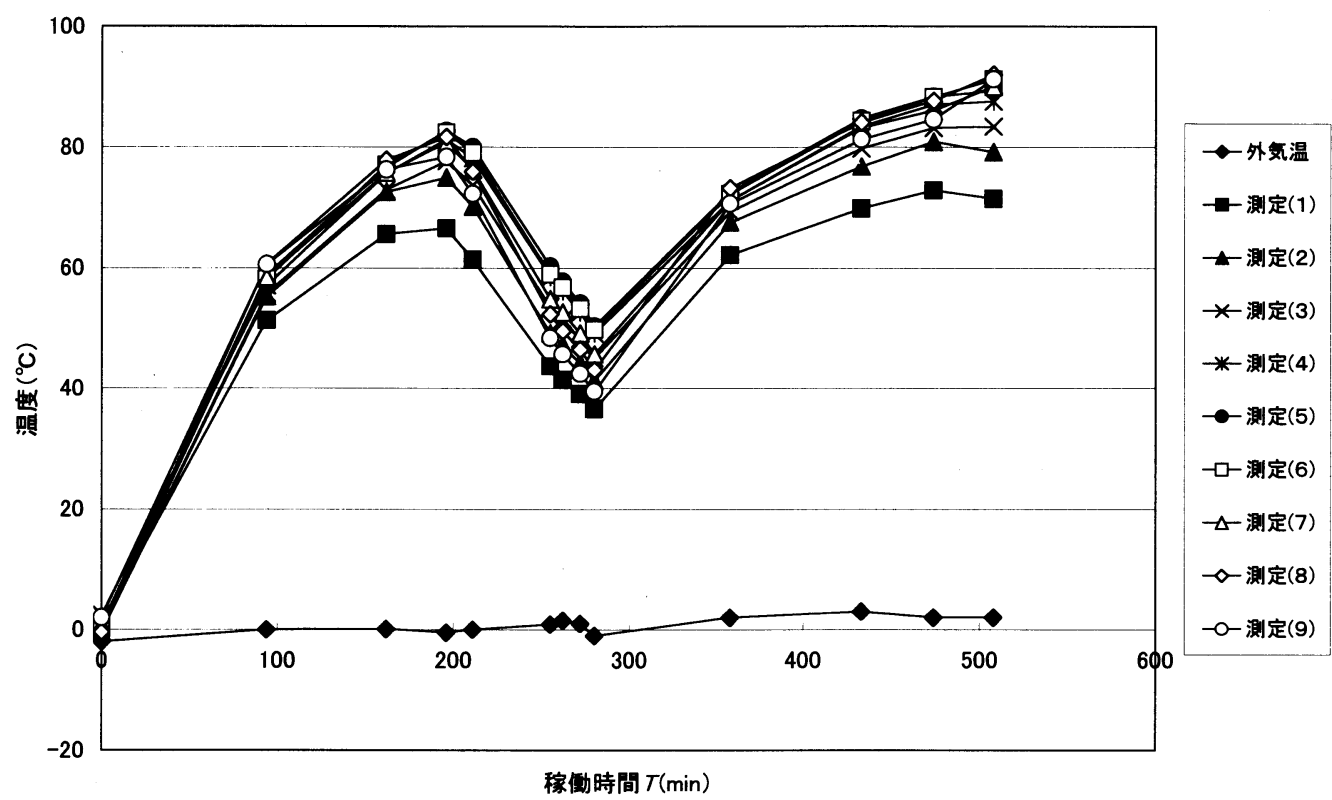

図一6 規格内圧時のカーカス近傍温度変化

本調查は規格内圧に調整し，8 時間の測定を行った. 図 -5 は空気圧と稼働経過時間の関係を示したものである. 始業から 9 ポイントの計測を行った.

空気圧は稼働開始約 200 分後には $840 \mathrm{kPa}$ に達してい る. その後稼働停止時（202２85 分）に一時减少し, 稼働再開後再び増加に転じている. 空気圧は重ダンプ トラックが稼働することにより増加し，稼働停止時に は減少するといえる. 測定中の最大空気圧は $857.5 \mathrm{kPa}$ を示し, 初期設定内圧との差 $171.5 \mathrm{kPa}$, 変動割合は $25 \%$
に達している. 従来, タイヤの空気圧に関しては一度 設定すれば，空気洩れがない限り一定であると見なさ れてきた. しかし，今回のような規格内圧に設定した 空気圧において顕著な変動が確認された.

空気圧の変動により, 接地圧, 接地面積, タイヤの 弾性係数, 転がり抵抗，荷重支持能力等が変化する ${ }^{5)}$ ， 9. 変動割合が $25 \%$ に達することは，これらの変化も大き くタイヤの性能に大きな影響を与える. また, 緒言に 述べたような操作性の変化をオペレータが感得する状 


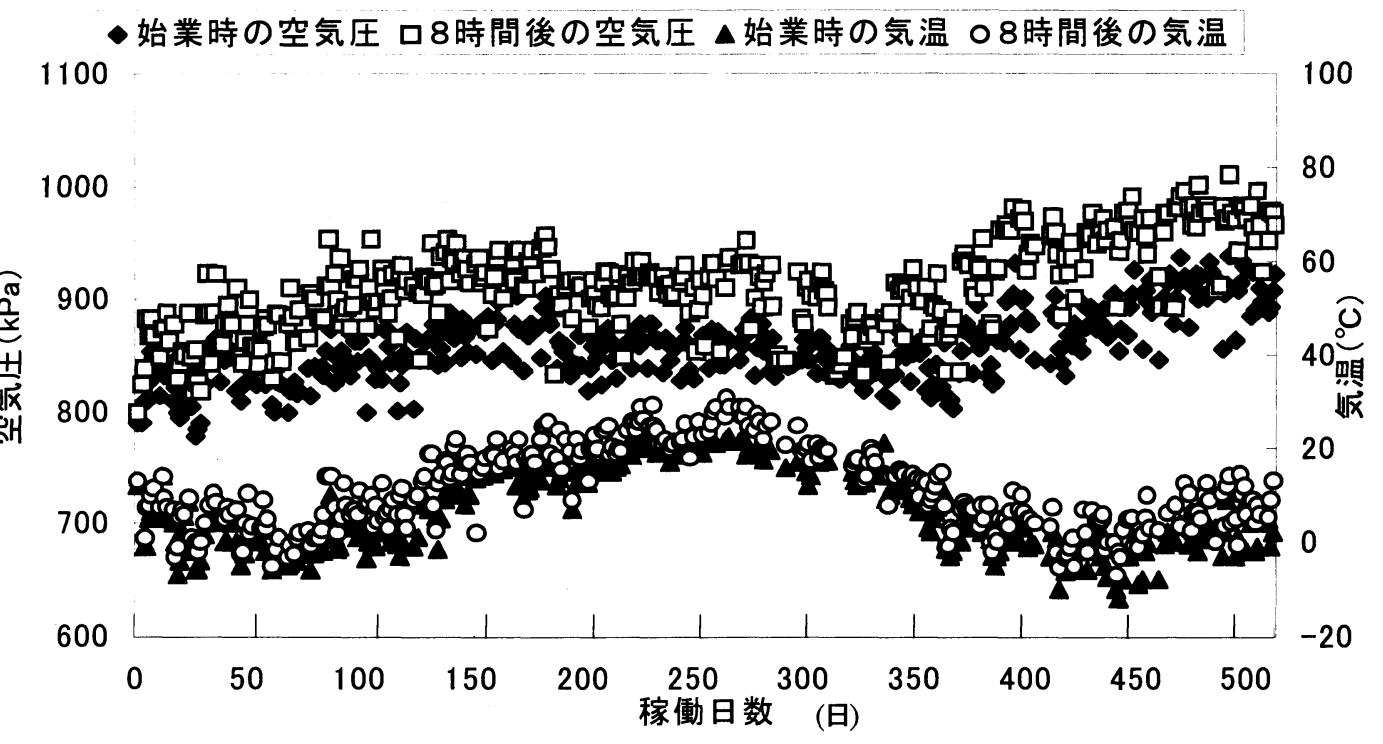

図-8 初期空気圧 $850 \mathrm{kPa}$ における空気圧変動

態を引き起こし，安定した作業環境を提供できない状 況になっていると考えられる.

\section{b)力一カス近傍温度}

$180 \mathrm{tf}$ 積み重ダンプトラックタイヤについて規格内圧 に初期設定した場合のカーカス近傍温度を内圧測定と 並行して行った. 図ー6 はトレッドゴム内におけるカー カス近傍温度と稼働経過時間との関係を示したもので ある. 図一7 は温度測定箅所を示している. 平均外気温 は $0.9^{\circ} \mathrm{C}$ であった. 図一5 の規格内圧時の空気圧変動同 様にカーカス近傍温度は稼働開始直後から上昇し, 稼 働停止時には下降している. カーカス温度は最高で $90^{\circ} \mathrm{C}$ を超えている. トレッド中心線を境に相対的に測点 (6) （9）の温度が高くなっている. これらの測点は車体 の内側に位置している. 本実験中の旋回方向がほぼ一 定であったために, 旋回時のトレッド面内の週速度差 により測点（6）～（9）側が若干ブレーキング状態にあ ったことが原因として考えられる.

図-5 の稼働日内の空気圧と図一6 のカーカス近傍温 度について, 空気圧を $Y(\mathrm{kPa})$, カーカス近傍温度の 平均值を $X\left({ }^{\circ} \mathrm{C}\right)$ とすると単回帰分析により式(1)を得 る.

$$
Y=1.87 X+688
$$

右辺第 2 項は初期空気圧であり $A$ と置き, 第 1 項の係 数を $k$ とおけば次式で表すことができる.

$$
Y=k X+A
$$

この式により初期空気圧が決定すればカーカス近傍 温度より空気圧を算出できる. 相関係数を計算すると
0.99 となり高い相関があるといえる. 外気温と空気圧 との相関係数は 0.38 となり, 空気圧とカーカス近傍温 度の相関係数 0.99 と比較すると小さい. 外気温が空気 圧に影響を及ぼしている可能性は低いといえる。

カーカス近傍の熱源としてはトレッド表面と地面と の摩擦による熱, カーカスとトレッドの相対運動によ る熱の 2 点が考えられる. 摩擦による熱によってトレ ッド表面の温度は上昇する. カーカス近傍とトレッド 表面の温度を比較するとタイヤ内部に位置するカーカ ス近傍の温度の方が高かった. 高温の物体と低温の物 体を接触させれば熱は高温物体から低温物体に伝わる ので, トレッド表面と地面との摩擦による熱はタイヤ 内部のカーカス近傍温度を上昇させる原因になってい ない.これよりカーカス近傍の温度上昇はカーカスと トレッドの相対運動による可能性が高いと考えられる. カーカスとトレッドの相対運動はタイヤの変形時にカ 一カスとトレッドの接着部分で起こる. タイヤは複合 材料でありトレッドとカーカスの弾性係数の違いによ り相対運動が起こり, タイヤの変形が大きいほど相対 運動も大きくなる. カーカス近傍の温度上昇がカーカ スとトレッドの相対運動によるものであるとすれば, カーカス近傍の温度上昇は気体の状態方程式よりタイ ヤ空気圧上昇の誘因となる.

空気圧変動とカーカス近傍温度の変化には高い相関 が認められており，これらの関係を遮断することによ って空気圧変動を抑えられる可能性がある. 


\section{c)通常稼動時の空気圧変動}

通常稼働時の空気圧変動の実現象を把握するため, 定時観測を行った. 本調査現場の $180 \mathrm{tf}$ 積み重ダンプト

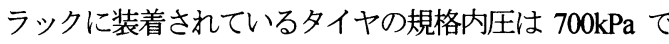
ある. しかし，本調査現場において実際に稼働してい る車両タイヤの初期空気圧はタイヤの形状を維持する ために規格内圧より高めに調整されている.

図-8 は平均初期空気圧 $850 \mathrm{kPa}$ における空気圧調査 の結果であり，始業時と 8 時間後の空気圧についてお よそ 500 日間続けて調査を行った. けは始業時空気圧， 口は 8 時間後の空気圧であり, 実稼働中の車両データ であるためトラブルによる休車，および休憩等の停止 も含んでいる．またムは始業時の外気温，○は 8 時間 後の外気温を示している. 始業時の平均空気圧は 858.3 $\mathrm{kPa} ， 8$ 時間後の平均空気圧は911.2 $\mathrm{kPa}$ であった. これ らの差は $52.9 \mathrm{kPa}$ であり，始業時空気圧の約 6\%の変 動が存在する.これに対して前述の規格内圧 $700 \mathrm{kPa} に$ 設定したものは, 初期内圧と 8 時間後の内圧の差が $171.5 \mathrm{kPa}$ であり， $25 \%$ の変動が存在した. 初期空気圧 を $850 \mathrm{kPa}$ に設定した場合の変動は規格内圧に設定した 場合の 4 分の 1 以下となった。これより調査を行った 石灰岩盤上のような硬い路盤上の条件では，初期内圧 を規格内圧より高内圧に設定する方が空気圧変動を抑 えることができるといえる.

一方，調査期間中に通常の空気圧管理によって人為 的に始業時の空気圧を変更した事例が 8 回あり，その 調整幅は $24.0 \mathrm{kPa}$ であった．調査期間中の平均空気圧 変動は $52.9 \mathrm{kPa}$ で，人為管理による変更幅の約 2.2 倍 である. 人為的な空気圧変更によってタイヤの機能は 十分に発揮できる状態が保たれるとされてきた. 通常 稼働時の平均 $52.9 \mathrm{kPa}$ の空気圧変動は, 人為管理によ る変更幅より大きくなっており空気圧管理において十 分に認識が必要である.

また通常稼働時の空気圧変動と外気温の関係につい ては，単回帰分析による空気圧と外気温の相関係数が 0.05 であることから，空気圧変動に外気温が影響を及 ぼしていないと考えられる.

初期平均空気圧 $950 \mathrm{kPa}$ についても同様に，通常稼 働時の空気圧変動を把握するためおよそ 400 日の期間 定時観測を行った. 平均初期空気圧 $850 \mathrm{kPa}$ の調査に 使用した車輛に新品タイヤを装着させた．始業時の平 均空気圧は $962.9 \mathrm{k} \mathrm{Pa}, 8$ 時間後の平均空気圧は 1021.1 $\mathrm{kPa}$ であった。 これらの差は $58.2 \mathrm{kPa}$ であり，始業 時空気圧の約 6\%の変動が存在する. 前述の平均初期空 気圧 $850 \mathrm{kPa}$ の結果は, 始業時と 8 時間後の空気圧の 差が $52.9 \mathrm{kPa}$ であり，始業時空気圧の約 $6 \%$ の変動が 存在した. 初期空気圧 $850 \mathrm{kPa}$ と $950 \mathrm{kPa}$ は通常稼働 時の空気圧変動幅がほぼ等しいといえる．初期空気圧
を規格内圧 $700 \mathrm{kPa}$ より高い $850 \mathrm{kPa}$ に設定すれば空 気圧変動を抑えることができたが，初期空気圧をさら に高い $950 \mathrm{kPa}$ に設定しても $850 \mathrm{kPa}$ の空気圧変動よ り抑えることができなかった.これより初期空気圧の 調整によって抑えることのできる空気圧変動には限界 があると考えられる.

初期空気圧を高く設定した場合においても年間を通 じて一稼働日内において空気圧変動を有していること が明らかになった．初期空気圧を高く設定した場合の 空気圧は規格内圧時と比較すると変動が小さくなり, タイヤの機能に与える影響も軽減できるといえる．し かし，この場合においても人為管理による空気圧変更 幅より稼働中空気圧変動幅の方が大きい，以上のこと から人為的に空気圧調整を行う際には空気圧が変動し ていることを前提とし，初期空気圧と稼働中に増加す る空気圧の変動幅を考慮して空気圧を調整する必要が ある．空気圧調整は稼働中及び稼働後の空気圧変動過 程の時に行うのではなく，前項の結果とあわせて外気 温とタイヤ温度がほぼ同じ時に調整するのが最適であ ると考えられる。

\section{（2）坂路を走行する重ダンプトラックの空気圧変動}

現場実験を行った 30tf 積み重ダンプトラックは車体 を屈折して操舵するアーティキュレートダンプトラッ クであり，前述の重ダンプトラックと比べて旋回半径 が小さい. 図-9 に示すような坂路で構成された走路を 重ダンプトラックが走行する場合, 走行条件の違いが 空気圧に及ぼす影響についての調査を行った．本テス 卜は積載量 $250 \mathrm{k} \mathrm{N}$, 稼働時間 3.5 時間とした. 空気圧 $600 \mathrm{k} \mathrm{Pa}$ に初期設定した場合の半日の変動を調査した. 空気圧測定は图ー9の $\mathrm{A} \sim \mathrm{C}$ の 3 ポイントで行った. $\mathrm{A}$ 地点は重ダンプトラックの操車場である. B 地点はべ ンチカットサイトであり掘削された石灰石が重ダンプ トラックに積み込まれるポイントである. C 地点は重 ダンプトラックによって運ばれきたずりを下ろす堆積 場である. まず $\mathrm{A}$ 地点で空車の状態で空気圧を測定し， 次に B 地点て積込を行った状態で空気圧を測定し，最 後に $\mathrm{C}$ 地点で実車の状態で空気圧を測定した. $\mathrm{A} \sim \mathrm{C}$ 地点で繰り返し測定を行った. 測定所要時間は 1 地点 につき約 2 分であった.

図一10 は空気圧と稼働経過時間の関係を示したもの であり，空気圧は 6 つのタイの平均値である．始業 から 19 ポイントの計測を行った. 破線は重ダンプトラ ックが $\mathrm{A} \sim \mathrm{B}$ 地点に移動している空車登坂時の空気圧 変動を示している. 同様に太い実線は実車時の $\mathrm{B} \sim \mathrm{C}$ 地点, 細い実線は空車時の $\mathrm{C} \sim \mathrm{A}$ 地点の空気圧変動を 示している. 空気压は始業開始直後から増加を始め, 180 分後には最大で $650 \mathrm{k} \mathrm{Pa}$ に達している. 初期空気圧と 


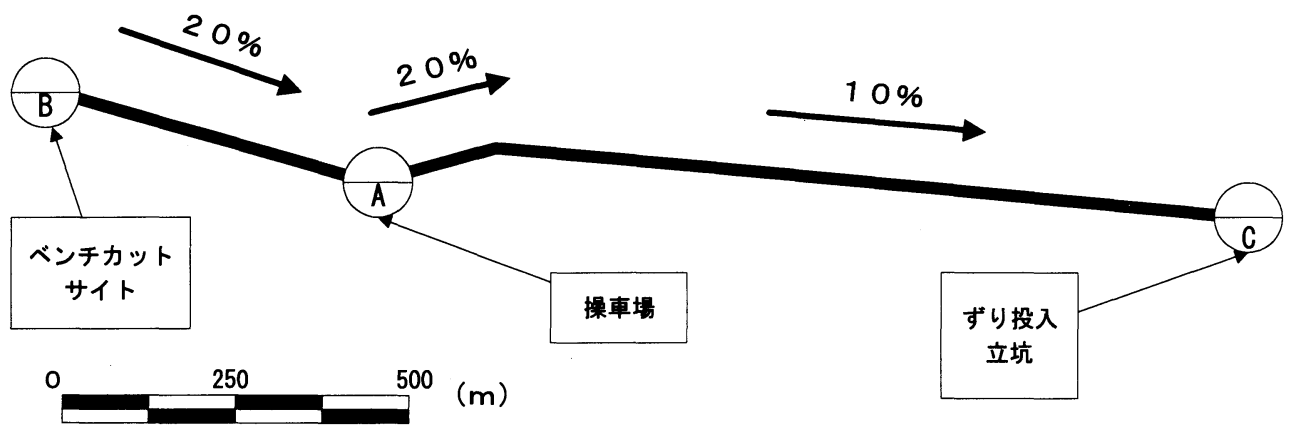

(注) $\mathrm{A} \sim \mathrm{B}$ 間 : 運搬距離 $450 \mathrm{~m}(20 \%$ 上り)

$\mathrm{B} \sim \mathrm{C}$ 間 : 運搬距離 $450 \mathrm{~m}$ (20\%下り)，運搬距離 $180 \mathrm{~m}$ （20\%上り），運搬距離 $1190 \mathrm{~m} （ 10 \%$ 下り） $\mathrm{C} \sim \mathrm{A}$ 間 : 運搬距離 $1190 \mathrm{~m}$ （10\%上り），運搬距離 $180 \mathrm{~m}$ (20\%下り)

図-9 走路縦断図

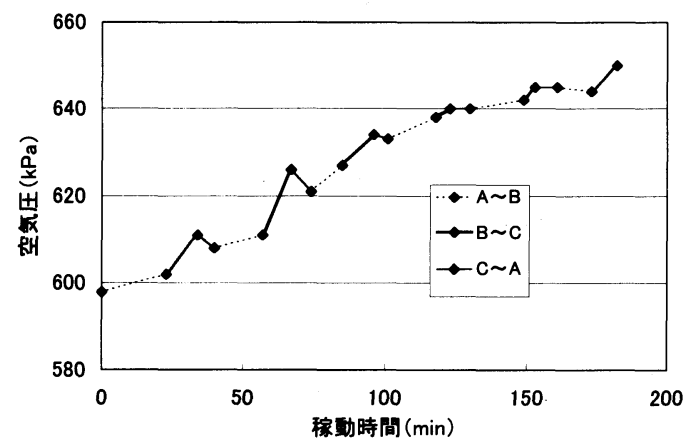

図ー10 30tf 積み重ダンプトラックタイヤの空気圧変動

180 分後の空気圧の差は $52.0 \mathrm{kPa}$ であり，初期空気圧の 9\%の変動が存在する. 始業から稼働時間 100 分に達す るまでの空気圧の変動が特に大きい. その変動は $38.6 \mathrm{kPa}$ で全体の変動の $74 \%$ である. 図-5 の $180 \mathrm{tf}$ 積み重ダンプトラックタイヤの規格内圧時の空気圧変 動も稼働時間 100 分に達するまでの変動幅が大きい. 空気圧が低い場合, カーカスとトレッドの相対運動が 大きく空気圧上昇幅が大きくなるといえる．空気圧の 上昇に伴ってカーカスとトレッドの相対運動が抑えら れることにより稼働時間 100 分付近を境に空気圧上昇 幅が小さくなったと考えられる. 坂路を走行する重ダ ンプトラックの半日の空気圧変動調査結果についても 平坦路を走行する重ダンプトラックの一稼働日内の変 動調査と同様, 稼働時間と共に増加した。

一方, 地点ごとの傾向としては $\mathrm{A} \sim \mathrm{B}$ 地点, $\mathrm{B} \sim \mathrm{C}$ の 地点で空気圧は増加して, C A 地点で空気圧は減少し
ている. 空気圧の最大増加量は $\mathrm{B} \sim \mathrm{C}$ 地点で $12.6 \mathrm{kPa}$ と なり, 最大减少量は $\mathrm{C} \sim \mathrm{A}$ 地点で $4.6 \mathrm{kPa}$ となった. 最 終的に空気圧は初期空気圧と比較して 52.0kPa 増加して いるが，勾配 $20 \%$ のりである $\mathrm{A} \sim \mathrm{B}$ 地点で $16.0 \mathrm{kPa}$ 増加し, 勾配 10〜20\%の下り中心である B C の地点 でさらに $39.6 \mathrm{kPa}$ 増加し, 勾配 10\%の上り中心である $\mathrm{C} \sim \mathrm{A}$ 地点で 3.6kPa 減少したことになる. 稼㗢中の夕 イヤは通常, 繰り返し圧縮を受けている. 繰り返し圧 縮はカーカスとトレッドの相対運動による発熱現象を 引き起こし, 空気圧上昇を起こす主たる原因になって いる. 勾配の大きい下りでは繰り返しブレーキ操作が 行われ，急激な圧縮がタイヤ内部の空気に伝わる. 大 きな制動力が発生するブレーキ操作が繰り返し行われ ると相対運動が大きくなり, 発熱量を増加させている. また調査に用いた 30tf 積み重ダンプトラックの空車重 量は $217 \mathrm{kN}$ であり最大積載量 $267 \mathrm{kN}$ を加えると総重 量は $484 \mathrm{kN}$ となる. 実車のタイヤには空車と比べて最 大で 2 倍強の負荷状態となる. 実車の状態では慣性力 が大きくなるため, ブレーキ操作を行う時間及び回数 が増える. B〜C 地点はタイヤにとって最も過酷な条件 であり，大きい相対運動が繰り返し起こることにより 空気圧上昇が大きくなったと考えられる. C A 地点で 空気圧が減少した原因としては， B C 地点が実車の下 りでカーカスとトレッドの相対運動が非常に活発にな っていたのに対して，C〜A 地点は空車の上りで相対運 動が抑えられたことが考えられる. 運搬車両の稼働を 考えた時, 実車後の空車状態における作業待ちの時間 が発生する状況が想定されるが，この場合は空気圧の 減少が大きくなると考えられる.

今回の現場実験により, 坂路で構成される走路にお 


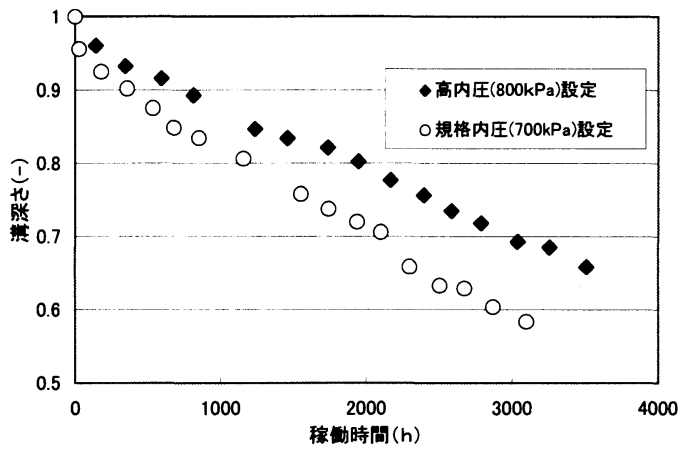

図ー11 $180 \mathrm{t} f$ 積重ダンプトラックタイヤの摩耗履歴

いて，勾配の大きい下りの実車の条件での空気圧上昇 が大きいこと判明した．走路設計においては，坂路を できるだけ少なくすることが肝要となるが 7), 稼働サイ クル中に作業待ちが生じると空気圧の増减が頻繁に起 こり得るため, 走路の配置の際に検討項目として挙げ られるものと考える.

\section{(3)タイヤの摩耗因子}

タイヤ空気圧が高くなると, タイヤの変形によるト レッドとカーカス間の相対運動が抑えられる可能性に ついては先に述べた.この場合トレッドと接触路艋間 の摩擦が低減されることが推測される. そこで, タイ ヤ空気圧設定を高くした場合のタイヤ摩耗に与える影 響について調べた. OR タイヤ空気圧は定格荷重に対し て標準的な空気圧が規格内圧として示されているが， OR タイヤが走行する路盤は軟弱地盤から硬路盤まで多 様であり，走行性を確保するためには一律に空気圧を 適用できない面がある. またローダ作業等における口 ードアンドキャリー工法の場合, 前後輪の荷重不均衡 による車両の不安定解消のため, タイヤ空気圧を $100 \mathrm{k}$ $\mathrm{Pa}$ 程度高く設定する場合がある.ここでは, タイヤ構 造上許容されると考えられる範囲において高内圧設定 を行い実験した.

図-11 は 180tf 積み重ダンプトラックの初期空気圧を 規格内压 $(700 \mathrm{kPa})$ と高内圧 $(800 \mathrm{kPa})$ に調整し, 稼 働時間とタイヤの溝深さを測定したものである.この 曲線を摩耗履歷曲線と呼んでいる． 測定開始時のタイ ヤの溝深さを規格内圧, 高内圧共に 1 とし, 各測定值 はその比として無次元化した. およそ 3000 時間後には, 規格内圧のタイヤと高内圧のタイヤの差は 0.1 となって おり顕著な差が現れている.

タイヤ空気圧を高く設定することにより摩耗を抑え ることに対する示唆は, 稼働時間の短い場合について 式(3)によって示されていたが 8)，9，今回の結果におい

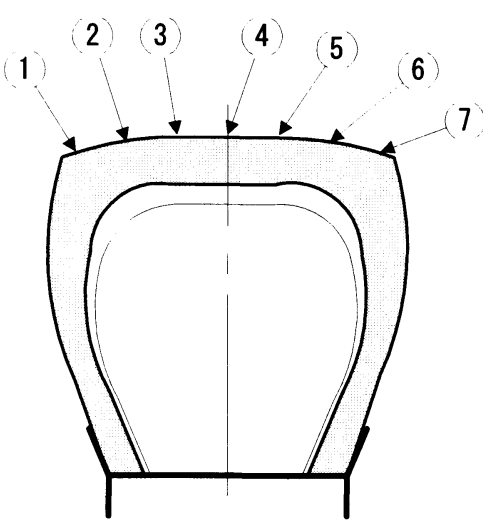

図-12 傷長さ測定個所

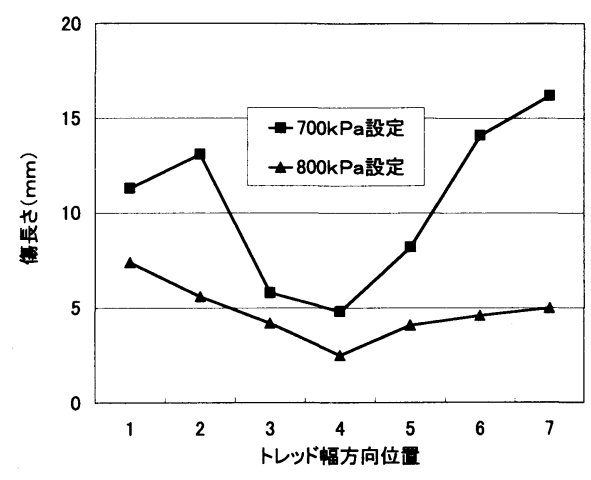

図ー13 空気圧設定の違いによる傷長さ

て運搬車両の大型化したタイヤについても，その事が 実証されたといえる.

$$
M_{V}=k \cdot B^{a} \cdot p^{b} \cdot q^{c}
$$

ここに, $M_{V}$ : 摩耗速度 $(\mathrm{mm} / \mathrm{h}), B$ : タイヤのト レット幅 $(\mathrm{cm}), p$ : 接地圧 $(\mathrm{kPa}), q$ : タイヤ空気 圧 $(\mathrm{kPa}), k, a, b, c$ : 現場走行特性によって得ら れる定数である. 文献 8)における現場データでは, $k$ : $9.60 \times 105, a:-2.01, b: 1.02, c:-2.61$ となってお り，一種類のタイヤに限定すればタイヤ空気圧の効果 が大きいことがわかる.

実験対象である砕石路の硬路盤条件ではタイヤ空気 圧を高く設定することによって摩耗を抑えることがで き, タイヤの寿命を延ばすことができるといえる.

次に摩耗との観点から，タイヤ空気圧の設定が実際 のトレッド表面と路盤間の相対的な動きにどのような 影響を与えているかについて調べるため, 以下の実験 を行った.

(1) 走行路盤上に鋼製盤を敷きその上に銅版シートを スクラッチ板として貼りつけ, 粒径 $2 \mathrm{~m} \mathrm{~m}$ 


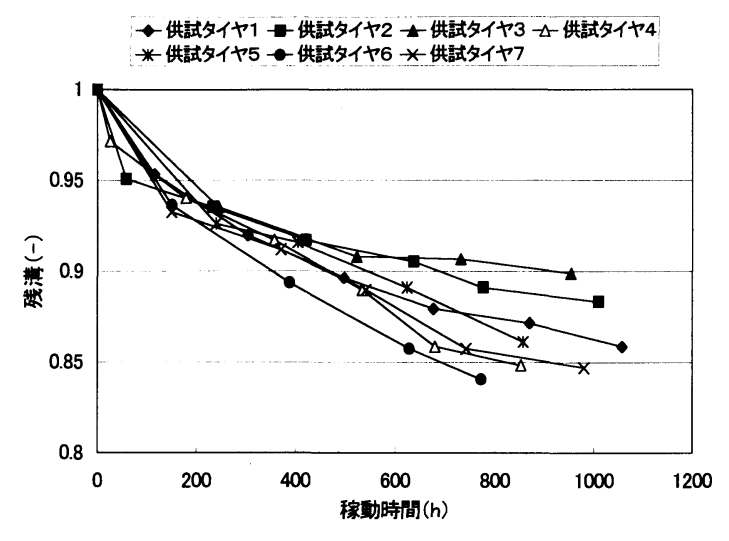

図-14 稼働初期の摩耗履歷

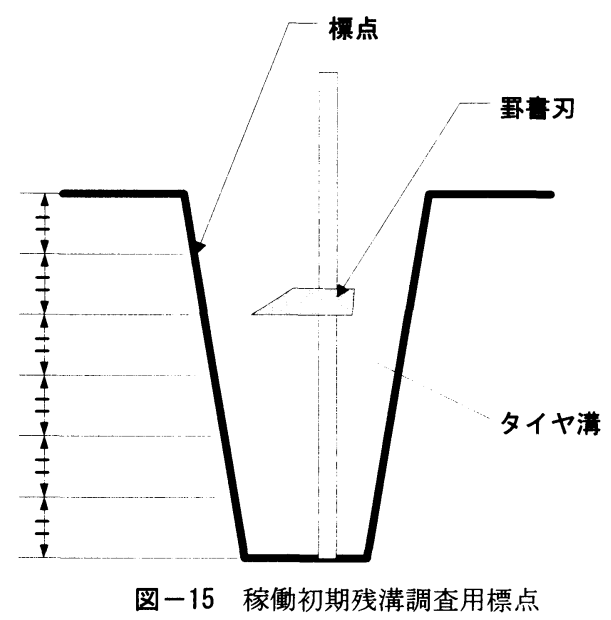

程度の石灰岩破砕粒をトレーサとして撒布する.

(2)スクラッチ板上を 2 種類のタイヤ空気圧にて走行 させ, 最も相対運動が大きいと考えられる制動状 態でトレーサによってスクラッチ板に傷を付けさ せる.

(3)スクラッチ板の傷を感圧紙に写し取り，傷長さを 分析する.

トレッド表面上の傷長さ測定箇所は図-12 の通りで ある. 図ー13 はトレッド幅方向の各位置における傷長 さの最大值を示したものである.

スクラッチ板の傷は, タイヤトレッド表面のゴムと トレーサである石灰岩破砕粒が一体となって動いた時 に発生したものと考えると，その長さはすべり長さと 見ることができる．すべり長さから摩擦仕事量が算定 できるが，これは摩耗を支配する要因であり，図一13か ら空気圧の高い場合にトレッド表面ゴムの動きについ
ても抑えられていることがわかり，摩耗の低減に寄与 しているといえる.

路盤とトレッドゴムの摩擦係数を $\mu$, すべり長さを $L(\mathrm{~m})$ ，接地圧を $p\left(\mathrm{~N} / \mathrm{m}^{2}\right)$ とすると, トレッド表面 の単位面積当りの摩擦仕事量 $J\left(\mathrm{~N} \cdot \mathrm{m} / \mathrm{m}^{2}\right)$ は次式で与 えられる。

$$
J=\mu \cdot L \cdot p
$$

別途収集したタイヤ幅方向の接地圧分布を基に, 各 測定点における単位面積当り摩擦仕事量を式 (4) にて 求めると, 図一12 測点 6 において,

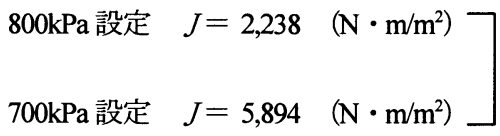

となり，700kPa 設定時の摩擦仕事量は $800 \mathrm{kPa}$ 設定時の 2.6 倍を超えている. 摩擦係数 $\mu$ は, 路盤とタイヤ間の

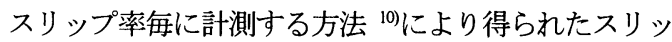
プ率ー $50 \%$ 時の 0.610 を用いた. トレッド面内の接地圧 がほぼ一定とみなせる範囲（測点 1 および 7 は含まな い) で最も大きな差が生じている箇所が測点 6 である. タイヤの空気圧設定が高くなると, それに伴い接地圧 も高くなるが，その場合においても本現場のような硬 路盤，高荷重下では路盤とタイヤ間の摩擦仕事量が小 さくなるという事実は十分に把握しておく必要がある といえる.

現場におけるタイヤ摩耗の管理は主としてトレッド 面に刻まれた溝の深さを計測することによって行われ ている．接地圧，タイヤ幅等の稼働条件が一定であれ ば，式（3）により摩耗速度はほぼ一定であると見るこ とができる．しかしながら，新品タイヤを装着した場 合, 稼働初期の溝深さの減少が大きいことが経験的に 知られている. 図-14 は複数の新品タイヤに関する稼 働初期のトレッド溝梁さの変化を計測した結果である。 空気圷設定は 800kPa である. 図一11 と同様，残溝は無 次元化して表示している. 稼働開始 200 時間程度まで に摩耗速度が変曲する位置が現れている，摩耗速度変 曲点以降の追跡調査の結果，摩耗速度と稼㗢時間との 関係は単回帰分析において，いずれも相関俰数 0.99 を 上回っており, 稼働初期の残溝量の処理を適切に行え ば高精度の摩耗予測が行えるものと考える.

稼働初期の残溝量减少状態を調べるため, 溝側面梁 さ方向に等間隔で羁書線を図ー15 の様に入れ標点とし， 標点間隔を測定した. その結果, 測定対象全てのタイ ヤについて標点間隔が狭まっていることがわかった. 稼動開始 160 時間において, 標点間隔変化量の総和は タイヤ 1 本平均 0.053 (無次元化表示) であった. 変曲 点以降の稼働 160 時間分の残溝减少量は 0.015 程度であ 
ることから，稼㗢初期においては見かけ上，約 3 倍強 の摩耗が生じていることになる．しかし測定の結果は 標点間隔の変化，すなわちトレッドゴムの変形の占め る割合が大きいことを示している. 安全側を選択すれ ば, 稼働開始 200 時間後の残溝量を測定し, この值を 基準として, 変曲点以降の安定した摩耗速度を適用す れば効果的な摩耗管理が為されると考える. いま, 稼 働開始 200 時間後の残溝量を $D_{200}(-)$, 変曲点以降 の摩耗速度を $M_{V E}(1 / \mathrm{h})$ ，稼働時間を $T(\mathrm{~h})$ と寸れ ば，ある稼働時間における残溝量 $D_{i}($ - ）は,

$$
D_{i}=D_{200}-M_{V E} T \quad(T>200 \mathrm{~h})
$$

となる. 稼働初期の残溝減少を加えた摩耗履歴曲線を 多項式近似すると高次項を含むが，式（6）によれば1 次式で表示できる上に実現象との相関も高い，現場で の稼働管理を考慮した場合，有用性の高いものである と考えられる。

\section{5. 結論}

近年大型化する建設車両用大型 OR タイヤについて空 気圧変動の害態把握を行うことを目的とした. 重ダン プトラックの OR タイヤについて空気圧を測定し, 硬 路艋条件におけるタイヤ空気圧に影響を及ぼす要因に ついて調査した. また, 空気圧と摩耗との関倸を現地 実験により明らかにし，摩耗を抑えることについて検 討した. 以下に得られた知見を示す。

(1)初期設定を規格内圧に設定した場合において，空 気圧は稼働状態により増加减少しており, 測定中 の変動割合は初期設定圧力の $25 \%$ に達する場合が ある. 空気圧の変動により, 接地圧, 接地面積, タイヤの弾性係数, 転がり抵抗, 荷重支持能力等 が変化していると考えられ，タイヤの機能に大き な影響を与えるといえる. 従来の大型 OR タイヤ の取扱いは稼㗢中の空気圧を一定と見なしてきた が，実際は大きな空気圧変動を有していることが 明らかになった。

(2)カーカス近傍の温度上昇はカーカスとトレッドの 相対運動によるものであり, カーカス近傍の温度 変化が空気圧変動の要因となっていると考えられ る. 空気圧の変動とカーカス近傍温度の変化には 高い相関が認められ，これらの関係を遮断するこ とによって空気圧変動を抑えられる可能性がある.

(3)初期空気圧を高く設定した場合の空気圧は規格内
圧時と比較すると変動が小さくなり, タイヤの機 能に与える影響も軽減できるといえる. しかし， この場合においても人為管理による空気圧変更幅 より稼㗢中空気圧変動幅の方が大きい. このこと から人為的に空気圧調整を行う際には空気圧が変 動することを前提とし, 初期空気圧と稼働中に増 加する空気圧の変動幅を考慮して空気圧を調整す る必要がある. 空気圧調整は稼働中及び稼働後の 空気圧変動過程の時に行うのではなく, 外気温と タイヤ温度がほぼ同じ時に調整するのが最適であ ると考えられる.

(4)坂路を走行する重ダンプトラックの空気圧変動は 平坦路走行重ダンプトラックの一稼働日内の変動 之同様, 空気圧が稼働時間と共に増加した. また, 勾配の大きい下りの実車の条件で空気圧上昇が大 きいことが明らかとなった.

(5)タイヤ空気圧を高く設定することによりタイヤの 荷重によるたわみ変形量を小さくすることができ， たわみ変形によるトレッドと路盤の摩擦を軽减で きる．硬路盤においてはタイヤ空気圧を高く設定 することにより摩耗を遅らせ, タイヤの寿命向上 対策に一定の効果を発揮する.

(6)タイヤ摩耗履歴を管理する上で, 稼働初期のトレ ッドゴム変形による残溝减少を考慮し, 稼働開始 200 時間後の残溝量を基準とした式を用いること によって, 高精度の摩耗予測が期待できる.

謝辞 : 本研究の現地作業に際し, 西川裕雄氏（西川夕 イヤ(有)），日鉄鉱業(侏の各位には多大なご協力をいた だいた.ここに記して感謝する次第です。

\section{参考文献}

1) テラメカニックス研究会 : オフロードタイヤ工学, pp. 1〜2, 1999.

2）室達朗 : テラメカニックスー走行力学一, 技報堂出 版, pp.90 91, 1993.

3）及川晃：建設機械用タイヤの寿命と向上策, 建設機 械, p p.48 50, 1987.

4) 平川利夫 : 建設機械用タイヤの摩耗要因, 建設機械, pp. $58 \sim 61,1994$.

5）室達朗, 江口忠臣：ORタイヤのモデル化に関する 一考察, 平成 10 年度建設機械と施工法シンポジウ 
ム論文集, pp.208 211， 1998.

6) 江口忠臣, 室達朗 : 離散化タイヤモデルによる建設 車両用タイヤの基礎的変形性状解析, 土木学会論文 集 No.665/VI-49, pp.81-90, 2000.

7) テラメカニックス研究会 : 土砂摩耗の話一建設機械 作業部品一, pp. 175 188, 2000.

8) Muro, T. : Wear rate characteristics of heavy dump truck tyres, Journal of Terramechanics, Vol.26, No.1, pp.11 〜23, 1989.
9) 室達朗: 建設機械用土砂摩耗部品の寿命向上策, 建 設機械, pp.19〜22, 1987.

10) 室達朗 : 重ダンプトラックタイヤの摩耗履歷特性, 土木学 会論文集，第336 号, pp.149-157, 1983

\section{EFFECTIVE MANAGEMENT OF LARGE SIZED OFF THE ROAD PNEUMATIC TIRE FOR RUNNING ON THE CRASHED STONE ROADBED}

\section{Tadaomi EGUCHI and Tatsuro MURO}

The purpose of this study is to grasp the actual variation in the inflation pressure of large sized off- the- road pneumatic tires. So far the inflation pressure of a tire was regarded as in constant under operation. In this research, the variation of inflation pressure was investigated in detail for a period of five hundred days. It was observed that the variation of the inflation pressure is accompanied by the variation of the temperature near the tire carcass. Furthermore, it was verified that the variation in the inflation pressure causes changes of load capacity, profile, contact pressure distribution and form of wear. As a result, that the air pressure fluctuation could be controlled by using heat insulator between air layer and carcass. In addition to the aspect of conventional inflation pressure control, the research also involves various aspects of tire performances. 